\title{
Emergency Measures of Protection in International Arbitration
}

\author{
Monika Feigerlová ${ }^{1}$ \\ Institute of State and Law of the Czech Academy \\ of Sciences, Czech Republic \\ monika.feigerlova@ilaw.cas.cz
}

FEIGERLOVÁ, Monika. Emergency Measures of Protection in International Arbitration. International and Comparative Law Review, 2018, vol. 18, no. 1, pp. 155-177. DOI: 10.2478/iclr-2018-0030.

\begin{abstract}
Summary: Numerous arbitration rules were amended over the last five years to include provisions on the so-called emergency arbitration measures. An emergency arbitrator is appointed before the constitution of a full arbitral tribunal and is empowered to grant an interim relief that the applicants could have historically obtained in these urgent situations from ordinary courts only. The article discusses key aspects and challenges of the new institute in the context of both international commercial and investment arbitration.
\end{abstract}

Keywords: emergency arbitrator, emergency relief, pre-arbitral interim measures, emergency arbitrator rules, enforcement

\section{Introduction}

Emergency arbitrator mechanisms are a relatively new phenomenon in international arbitration. Standard provisional measures (be it measures granted by ordinary courts or by arbitral tribunals) might not appropriately accommodate needs of the parties in situations which require quick and effective action, be it securing assets that form the subject matter of the arbitration, maintaining status quo until the dispute has been decided or suspending parallel proceedings. In some instances, it can take weeks or months to constitute an arbitral tribunal that is empowered to grant such "first aid" relief. Requesting a national court for urgent interim relief before the arbitration proceedings have started or the arbitral tribunal has been appointed might be an unattractive option for applicants in certain circumstances or such an option can be even impossible.

1 JUDr. Monika Feigerlová, LL.M., PhD., Institute of State and Law of the Czech Academy of Sciences, Prague, Czech Republic (monika.feigerlova@ilaw.cas.cz), Attorney-at-Law. The paper was created under subsidies for long-term conceptual development of the Institute of State and Law of the Czech Academy of Sciences, Czech Republic, Identity Code RVO: 68378122 . 
In an attempt to make emergency interim measures available, in recent years a number of arbitral institutions have introduced special rules on the use of "emergency arbitrators" to determine applications for interim relief before the arbitral tribunal is constituted (e.g. SCC Arbitration Rules, SIAC Arbitration Rules, AAA/ ICDR Arbitration Rules, ICC Arbitration Rules, the Swiss Rules of International Arbitration or LCIA Arbitration Rules). A review of data from the arbitral institutions involving international arbitration reveals that parties are using the emergency arbitrator procedure ${ }^{2}$ and that the users' response to the mechanism is so far positive. Decisions of emergency arbitrators are generally rendered within extremely short time frames varying in the rules from 5 to 15 days.

Although the rules have been primarily designed to meet the needs of international commercial disputes, the benefits of interim measure in the context of international investment disputes are significant as well. Traditionally investment arbitration has relied on the procedural rules and enforcement mechanisms that have been developed largely in the context of international commercial arbitration. At present emergency arbitrator procedure is not available under the ICSID Arbitration Rules or the UNCITRAL Arbitration Rules under which the majority of investment treaty cases is decided. In accordance with the interpretative guidelines of the ICC Commission, neither the ICC Arbitration Rules containing emergency arbitrator mechanism apply to investment disputes. First cases rendered under the SCC Arbitration Rules that do not distinguish between commercial and investment state-party disputes have, however, proved that claimants in investment cases also call for this type of expedited procedure. Interim measures granted as an emergency may provide means to challenge the most outrageous conduct by a host State before the constitution of the arbitral tribunal.

2 According to its statistics, the Arbitration Institute of the Stockholm Chamber of Commerce administered 13 emergency arbitrator proceedings in 2016, which was a sharp increase from 2015. In 2017, the number of emergency decisions reached 3. See SCC Statistics. [online]. Available at: <http://www.sccinstitute.com/statistics/>. Accessed: 1.3.2018. Singapore International Arbitration Centre reports 57 received applications for emergency arbitration proceedings between 1 July 2010 and 31 March 2017. See SIAC statistics [online]. Available at: <http://siac.org.sg/2014-11-03-13-33-43/facts-figures/ statistics $>$. Accessed: 1.3.2018. According to the 2017 ICC Dispute Resolution Statistics, the total number of applications filed before the ICC to date amounts to 78. In 2017, 21 cases were filed and a further eight cases have already been recorded in 2018. See ICC Dispute Resolution Statistics [online]. Available at: https://iccwbo.org/media-wall/newsspeeches/icc-announces-2017-figures-confirming-global-reach-leading-position-complex-high-value-disputes/. Accessed: 1.3.2018. Under the Swiss Arbitration Rules, 7 cases were assessed by emergency arbitrators between years 2014 and 2016. See Swiss Chamber's Arbitration Insitution's Statistics. [online]. Available at: https://www.swissarbitration.org/ files/620/untitled\%20folder/Emergency\%20Proceedings\%20under\%20the\%20Swiss $\% 20$ Rules\%20(2017).pdf/>. Accessed: 1.3.2018. 
The aim of this article at is to explore the pre-arbitral emergency procedures, in particular the role and appointment of emergency arbitrator, types of measures and their enforcement, by way of comparison of the main arbitration rules that have adopted the possibility of emergency measures. I will also briefly analyze the legal basis of emergency arbitrator rules and will conclude with challenges posed in the investment arbitration context.

\section{General principles of Emergency arbitrator procedures}

Arbitration has been always viewed as a fast and effective procedure for resolution of commercial disputes. ${ }^{3}$ However, when an urgent relief is needed at the outset of the dispute arbitration lags behind measures offered by courts. If arbitration is to be equally efficient as judicial bodies, it must provide an equivalent system of interim protection of parties' rights. As a response to such need a number of arbitral institutions have introduced special rules on the use of "emergency arbitrators" to determine applications for interim relief before the arbitral tribunal is constituted (e.g. in the first wave SCC Arbitration Rules, ${ }^{4}$ SIAC Arbitration Rules, ${ }^{5}$ AAA/ICDR Arbitration Rules, ${ }^{6}$ ICC Arbitration Rules, ${ }^{7}$ the Swiss Rules of International Arbitration, ${ }^{8}$ followed by e.g. LCIA Arbitration Rules ${ }^{9}$ ).

The problem is, nonetheless, not new. In the past, some arbitral institutions already devised a range of different solutions to enable parties to take immediate action in urgent situations within the framework of international arbitration process (e.g. summary arbitral proceedings for interim relief, expedited formation of the arbitral tribunal or pre-arbitral referee procedure). These methods proved to be insufficient in situations requiring an immediate action. Some of

3 See e.g. BLACKABY, Nigel, PARTASIDES, Constantine, et al. Redfern and Hunter on International Arbitration. Oxford University Press, 2009, pp. 1-2.

4 Arbitration Rules of the Arbitration Institute of the Stockholm Chamber of Commerce. Emergency arbitrator was introduced in the rules valid as of 1 January 2010 and the mechanism is again available in the revised rules valid as of 1 January 2017.

5 Arbitration Rules of the Singapore International Arbitration Centre. Emergency arbitrator was introduced in the 4th Edition of the rules valid as of 1 July 2010 and the mechanism has been also made available in the later revised versions of the rules with the most recent one being the 6th Edition effective as of 1 August 2016.

6 International Dispute Resolution Procedures (including Mediation and Arbitration Rules) of the International Centre for Dispute Resolution of the American Arbitration Association. Emergency arbitrator was introduced in the rules valid as of 1 June 2009 and the mechanism is again available in the amended rules valid as of 1 June 2014.

7 Rules of Arbitration of the International Chamber of Commerce. Emergency arbitrator was introduced in the rules valid as of 1 January 2012 and the mechanism is again available in the amended rules valid as of 1 March 2017.

8 Swiss Rules of International Arbitration. Emergency arbitrator was introduced in the rules valid as of J June 2012.

9 The London Court of International Arbitration Rules (2014). Emergency arbitrator was introduced in the rules valid as of 1 October 2014. 
them did not find a wider application as their use was conditional upon a separate consent of the parties which was difficult to obtain once a dispute arose.

The primary objective of pre-arbitral emergency measures is to help parties to react quickly to an urgent situation before the passage of time renders any measure practically ineffective. Many arbitration laws and arbitration rules nowadays empower arbitral tribunals to grant provisional measures. ${ }^{10}$ The prerequisite, thus, is that the arbitral tribunal is already in place. The practice has shown that the time required for forming an arbitral tribunal was many times decisive for the effectiveness of certain types of provisional measures and in some instances appointing arbitrators turned out to be a time-consuming exercise. The time gap can also be manipulated and prolonged by the respondent party, for example by failure to pay its share on advance costs or by unfounded challenges of arbitrators.

The idea behind the emergency arbitrator procedure is to move forward the moment of adopting the measures to an earlier point in time. As a result, the parties are to obtain interim relief before arbitral proceedings have been initiated or before the arbitral tribunal has been constituted or before the file has been transmitted to the tribunal.

In the opposite case, the only option, that a party in need of urgent interim measure has, is to go to a national court of the relevant jurisdiction. While in many cases, such option will be viable and party will obtain a desired interim relief, in some instances, it might be inconvenient or impossible. For example, where the parties have validly excluded any state court jurisdiction, including the power to grant interim relief, or where parties are deprived from taking certain ordinary court actions for religious reasons. ${ }^{11}$ Parties might also find the court option undesirable just for the very reason that they have chosen arbitration for settlement of their disputes and wanted to avoid court proceedings where confidentiality is not the rule. They might also be hesitant to go to a court in the respondent's home jurisdiction.

\subsection{Forms of Emergency Arbitrator Procedures}

Urgent arbitrator procedures take many forms and operate under a number of different names. The common denominator of such procedures is the aim to offer to the parties to the arbitration agreement the possibility to seek interim measures (a) from an entity other than a state court and (b) before the arbitral tribunal has been constituted. Procedures further described in this article repre-

10 The Czech Republic is one of the countries that limit the power to grant interim measures to ordinary courts, in respect of both the domestic and international arbitration proceedings. See provision 22 of Act no. 216/1994 Sb., Act on Arbitration proceedings and Enforcement of Arbitral Awards, as amended.

11 For more details, see e.g. BOOG, Christopher. Swiss Rules of International Arbitration Time to Introduce an Emergency Arbitrator Procedure? ASA Bulletin, 2010, 3, pp. 463-465. 
sent institutionalized procedures. Parties are obviously free to adopt any ad hoc solution. This is though very rare in practice.

\subsubsection{Old Regimes}

In the past some institutions created rules providing for urgent interim relief. In 1990, the ICC introduced Pre-Arbitral Referee Procedure, in 1998 the LCIA added to its rules an expedited formation of the arbitral tribunal in urgent situations, and in 2001 the Netherlands Arbitration Institute (NAI) launched Summary Arbitral Proceedings. These early procedures, except for the NAI Rules, vary from what we today call emergency arbitrator procedures and will be briefly described below.

\section{a) ICC Rules for a Pre-arbitral Referee Procedure}

ICC was the first arbitration institution to offer parties an out-of-court mechanism for urgent interim relief. The ICC Rules for a Pre-Arbitral Referee Procedure in force as from 1 January 1990 were introduced to "enable parties that have so agreed to have rapid recourse to a person (called a "Referee") empowered to make an order designed to meet the urgent problem at issue, including the preservation or recording of evidence". ${ }^{12}$

The ICC Rules for a Pre-Arbitral Referee Procedure are a free-standing set of rules. They are neither part of the ICC Arbitration Rules nor the ICC Arbitration Rules contain any reference to them. Parties have to expressly agree on their application. The opt-in approach resulted in their rare use. The first application under the rules was filed only in 2000. In 2005, the ICC published a model arbitration clause with the "opt-in" of these rules in order to increase the users' awareness and support of their application. Nonetheless, according to the ICC the use of the procedure remained modest. ${ }^{13}$

The request for a pre-arbitral Referee is made to the Secretariat of the ICC Court. The Chairman of the ICC Court appoints the Referee, unless the parties mutually select the Referee. There is no official list of potential Referees, but the rules set out criteria to be taken into account when appointing a Referee, e.g. technical and professional qualifications, nationality and residence. ${ }^{14}$

The Referee can order conservatory and interim measures, payment, injunctions to perform a contractual duty, production and/or preservation of evidence. ${ }^{15}$ Further, its powers can be altered by the agreement of the parties.

12 See the Introduction Clause of the ICC Rules for a Pre-Arbitral Referee Procedure.

13 Only 14 pre-arbitral referee cases were reported to be filed with the ICC according to data available as at 2014 .

14 Article 4.4 of the ICC Rules for a Pre-Arbitral Referee Procedure.

15 Ibid., Article 2. 
The Referee shall make a decision in the form of "an order giving reasons" within 30 days from the transmittal of the file. ${ }^{16}$ The prevailing view among French scholars is that the decision is not a "jurisdictional" decision but a decision of a "contractual nature". ${ }^{17}$ Although not fully addressed in the French case law, it appears that enforcement of the order is not entitled to benefit from arbitration law and applicable treaties. This uncertainty was one of the reasons why drafters of the revised ICC Arbitration Rules formulated new provisions on emergency arbitrator procedures rather than including the ICC Rules for a Pre-Arbitral Referee Procedure into the arbitration rules as an opt-out solution. ${ }^{18}$

\section{b) Expedited Formation of the Arbitration Tribunal under LCIA Arbitration Rules}

The LCIA Arbitration Rules developed a distinctive procedure for an expedited formation of the arbitral tribunal in "exceptional urgency, on or after the commencement of the arbitration." 19 The LCIA Court may, in its complete discretion, "abridge or curtail any time-limit under the Rules for the formation of the tribunal." ${ }^{\prime 20}$

In combination with the power of the tribunal to order interim measures, ${ }^{21}$ the fast constitution of the arbitral tribunal allows that urgent applications for interim measures are heard without delay. Contrary to all other procedures described in this article, it is not a "true" pre-arbitral interim measure procedure. The effect is only to significantly shorten the process of tribunal formation. Such tribunal has the same powers and is subject to the same rules as any other LCIA arbitration tribunal. The same arbitral tribunal will, thus, decide both about the request for urgent interim relief and the merits of the case.

\subsubsection{New Regimes of Emergency Arbitrator Procedures}

The newest trend in filling the vacuum before the constitution of the arbitral tribunal is the appointment of a solo emergency arbitrator at very short notice. The International Centre for Dispute Resolution, the American Arbitration Association's international division, amended its International Arbitration Rules ("AAA/ ICDR Rules") to add this new institute of emergency arbitrator already on 1 May 2006. In a similar fashion the SCC Arbitration Rules were revised as from 1 January 2010 followed by revisions of the SIAC Arbitration Rules as from 1 July 2010

16 Ibid., Article 6.

17 See Decision of the Cour d'Appel de Paris, 29.4.1993, Société Nationale des Pétroles du Congo et Republic de Congo v Société Total Fina Ef.

18 BÜHLER, Michael. ICC Pre-Arbitral Referee and Emergency Arbitrator Proceedings Compared. ICC International Arbitration Bulletin., 2011, vol. 22, Special Supplement, pp. 93-98.

19 Article 9 of the LCIA Rules. The expedited formation procedure applies not only for the requested interim relief but also in general.

20 Ibid., Article 9.3.

21 Ibid, Article 25. 
and the ICC Arbitration Rules as from 1 January 2012.2. The latest addition to the family of emergency arbitrator procedures was the Swiss Arbitration Rules as from 1 June 2012 and the LCIA Arbitration Rules as from 1 October 2014.

Each of these sets of rules provides for the appointment, in cases of urgency, of a sole emergency arbitrator to resolve requests for temporary measures prior to constitution of the full arbitral tribunal. As soon as the full tribunal is constituted, the arbitrator responsible for considering initial requests for provisional measures ceases to play any further role in the arbitral proceedings.

\section{Comparative analysis of the selected emergency arbitrator procedures}

The below analysis is based on the comparison of the main characteristics of the emergency arbitrator procedures contained in the arbitration rules of the leading arbitration centers, namely the SCC Arbitration Rules, the ICC Arbitration Rules, the SIAC Arbitration Rules, the AAA/ICDR Arbitration Rules, the Swiss Arbitration Rules, and the LCIA Arbitration Rules.

\subsection{Opt-in or Opt-out Approach and the Issue of Retroactive Application}

One of the main questions regarding the emergency arbitrator procedures is whether the mechanism is available to the parties only if they explicitly agree to the relevant provisions on the emergency arbitrator (the so-called opt-in approach) or whether a parties' agreement to the relevant institutional arbitration rules automatically renders the emergency arbitrator procedure applicable, unless the parties expressly agree otherwise (the so-called opt-out approach). In order to answer this question it is necessary to look at how the emergency arbitrator provisions are incorporated into the applicable arbitration rules and when they are to be invoked.

In contrast to the approach of the old regimes, the emergency arbitrator provisions in all the compared arbitration rules adopt the opt-out solution and their automatic application. Parties must, therefore, expressly opt out of the emergency provisions if they do not wish them to apply. ${ }^{23}$

It appears that the opt-out approach was chosen to ensure that the procedure would be of use. At the time of drafting a contract parties are often unaware of the possibility to include a special provision into their arbitration clauses to opt in to the pre-arbitral process and they rather make a simple reference to the chosen arbitration rules. The opt-in is then never exercised. Moreover, the expe-

22 Also other institutions such as International Institute for Conflict Prevention and Resolution or Australian Centre for International Commercial Arbitration replicated the Emergency Arbitrator provisions.

23 See e.g. Appendix II of the SCC Arbitration Rules, Article 9.14 of the LCIA Arbitration Rules, Article 43 of the Swiss Arbitration Rules. 
rience with the old regimes has shown that a separate set of rules and the opt-in approach resulted in little use of such mechanisms.

A related question arises as to whether to apply the new procedures to all arbitration proceedings commenced after the revision of the rules or only to arbitration agreements concluded thereafter. From the compared arbitration rules, the SCC Arbitration Rules, the SIAC Arbitration Rules and the Swiss Arbitration Rules have taken the broadest approach and apply the emergency arbitrator provisions retroactively.

For example, the emergency arbitrator provisions apply to all SCC arbitrations commenced after 1 January 2010. This means that also arbitration agreements concluded before 1 January 2010 will be automatically subject to the new emergency provisions. Although at the time of entering into the arbitration agreement the parties may not have reasonably anticipated that the emergency arbitrator provisions will come into force and be automatic part of the SCC Arbitration Rules. In Sweden, the retroactivity generated a number of comments during the preparation of the new SCC Rules. It was finally justified by procedural efficiency and clarity of the applicable rules. ${ }^{24}$ So far emergency arbitrators appointed under the SCC Arbitration Rules have been refusing arguments of the respondents that the respondents had not consented to submit to emergency proceedings as the emergency arbitrator provisions were not part of the SCC Arbitration Rules when the arbitration agreement was signed. The principal argument used by the emergency arbitrators was that it is generally accepted that an arbitration clause is deemed to reference the version of the rules in force when the arbitration is initiated. ${ }^{25}$

In a similar manner under the Swiss Arbitration Rules the applicability of the emergency relief provisions is determined by the date on which the Notice of Arbitration is submitted and not by the date the arbitration agreement has been concluded. ${ }^{26}$ As reported on the Swiss Chambers' Arbitration website, the applicability of the emergency arbitrator provisions has been already challenged in one of the arbitration cases. The respondent argued that the emergency arbitrator lacked jurisdiction to decide upon the application for emergency relief due to the fact that the arbitration agreement was concluded at the time when the previous version of the Swiss Arbitration Rules was valid, which did not contain emergency arbitrator provisions. The emergency arbitrator confirmed its jurisdiction stating that the arbitration agreement in the given case referred to

24 For detailed comments on the pros and cons of the retroactive application of the emergency arbitrator rules, see e.g. SHAUGHNESSY, Patricia. Pre-Arbitral Urgent Relief: The New SCC Emergency Arbitrator Rules. Journal of International Arbitration, 2010, vol. 27, no. 4, pp 350-354.

25 See HAVEDAL, Anja. SCC Practice Note. Emergency Arbitrator Decisions Rendered 2015-2016. [online]. Available at: http://www.sccinstitute.com/media/194250/ea-practicenote-emergency-arbitrator-decisions-rendered-2015-2016.pdf Accessed: 1.3.2018, p. 17.

26 Articles 1(3) and 43(1) of the Swiss Arbitration Rules. 
the Swiss Arbitration Rules „in force on the date when the notice of arbitration is submitted", and that the parties had not opted out the emergency arbitrator provisions. $^{27}$

By contrast, the ICC Arbitration Rules and the LCIA Arbitration Rules exempt the application of the emergency arbitrator provisions where the arbitration agreement was concluded before the new rules come into force. ${ }^{28}$ The ICC Rules drafters recognized the "dramatic change introduced by the new provisions" which should be minimized. ${ }^{29}$ The statistics, nevertheless, do not indicate that the restricted applicability would cause a lesser number of received emergency arbitrator applications compared to the centers which have chosen a broader time framework for the application of the rules. Parties may apparently opt in or opt out of the emergency arbitrator provisions. The same "safe" method was also used in the AAA/ICDR Arbitration Rules.

\subsection{Appointment of the Emergency Arbitrator}

The emergency arbitrator is a sole arbitrator and is appointed at the request of a party by the relevant body of the arbitration institution. The SCC Board will "seek to appoint ${ }^{30}$ the emergency arbitrator within twenty-four hours", ${ }^{31}$ the Chairman of the SIAC appoints the emergency arbitrator "within one business day" ${ }^{32}$ the President of the ICC Court "within as short a time as possible", normally within two days, ${ }^{33}$ the ICDR administrator within one business day, ${ }^{34}$ the Swiss Chamber's Arbitration Institution will appoint the emergency arbitrator "as soon as possible after receipt of the Application, the Registration Fee, and the deposit for emergency relief", 35 and the LCIA Court shall appoint the emergency arbitrator "within three days of the Registrar's receipt of the application (or as

27 SWISS CHAMBER'S ARBITRATION INSTITUTE. Emergency Relief under the Swiss Rules (Art. 43): An overview after 4 years of practice. [online]. Available at: <https:// www.swissarbitration.org/files/620/untitled\%20folder/Emergency\%20Proceedings $\% 20$ under\%20the\%20Swiss\%20Rules\%20(2017).pdf>, Accessed: 1.3.2018, p 1.

28 Article 29(6)(a) of the ICC Arbitration Rules and Article 9. 14 of the LCIA Arbitration Rules.

29 See VOSER, Nathalie. Overview of the Most Important Changes in the Revised ICC Arbitration Rules. ASA Bulletin, 2011, no. 4, p. 815.

30 The wording "will seek to appoint " was chosen to provide some flexibility to depart from the strict 24-hour limit, when needed in complex cases or when there is a difficulty in obtaining a suitable emergency arbitrator. SHAUGHNESSY, Patricia. Pre-Arbitral Urgent Relief: The New SCC Emergency Arbitrator Rules. Journal of International Arbitration, 2010, vol. 27, no. 4, p. 341.

31 Appendix II, Article 4(1) of the SCC Arbitration Rules.

32 Schedule 1, Article 3 of the SIAC Arbitration Rules.

33 Appendix V, Article 2 (1) of the ICC Arbitration Rules.

34 Article 6.1 of the ICDR Arbitration Rules.

35 Article 43.2 of the Swiss Arbitration Rules. 
soon as possible thereafter)" ${ }^{36}$ Only the ICDR maintains a special panel from which it appoints the emergency arbitrators.

The emergency arbitrator may not act as an arbitrator in any future proceedings relating to the dispute, unless the parties agree otherwise. The ICC Arbitration Rules and the LCIA Arbitration Rules seem to be absolute and, even with parties' consent, do not allow the emergency arbitrator to act as an arbitrator in any arbitration relating to the dispute that gave rise to the application for emergency measures. ${ }^{37}$

Challenges of the emergency arbitrator are not excluded, but the entire procedure is speeded up. For example, under the SCC Arbitration Rules, a challenge must be brought within 24 hours of the time when the circumstances giving rise to the challenge became known to the party. ${ }^{38}$ The AAA/ICDR Arbitration Rules and the SIAC Arbitration Rules envisage one business day. ${ }^{39}$ The Swiss Arbitration Rules and the ICC Arbitration Rules stipulate three days from the notification of the appointment or from the day on which the party was informed of the facts and circumstance on which the challenge is based. ${ }^{40}$ The longest period is provided for in the LCIA Arbitration Rules under which the standard 14-day period applies. ${ }^{41}$

\subsection{Emergency Arbitrator Proceedings}

The procedure can be used by anyone who is a party to an arbitration agreement. Under the ICC Arbitration Rules, only signatories to the arbitration agreements and their successors may apply. ${ }^{42}$ This requirement excludes the so-called "extension-theories" under which a third party may be deemed to be bound by an arbitration agreement. This strict criterion in the ICC Arbitration Rules seeks to provide an alternative to the prima facie test of Article 6 and to resolve any jurisdictional doubts easily and rapidly at the outset. It shall ensure that only respondents who have agreed to ICC arbitration with the applicant can be involved in the emergency arbitrator procedures. This requirement will also preclude the use of the ICC emergency arbitrators in investor-state disputes, since they are not usually based on a signed individual arbitration agreement.

Emergency arbitrator proceedings are devised to assist parties in the context of relevant arbitration proceedings. Therefore, a submission starting the arbitra-

36 Article 9.6 of the LCIA Arbitration Rules.

37 See Appendix V, Article 2 (6) of the ICC Arbitration Rules.

38 Appendix II, Article 4(3) of the SCC Arbitration Rules.

39 Article 6.2 of the ICDR Arbitration Rules, Schedule 1, Article 5 of the SIAC Arbitration Rules.

40 Article 43.4 of the Swiss Arbitration Rules. Appendix V, Article 3 (1) of the ICC Arbitration Rules.

41 Article 10.3 of the LCIA Arbitration Rules.

42 Article 29(5) of the ICC Rules. 
tion proceedings needs to be served by the applicant together with the request for emergency relief or shortly thereafter. Under the SIAC Rules, parties are required to submit a Notice of Arbitration before or concurrently with a request for emergency relief. ${ }^{43}$ Similarly, pursuant to the LCIA Rules a party may make an application at the time of filing a Request for Arbitration, or at any time before the formation of the Arbitral Tribunal. ${ }^{44}$

On the other hand, the SCC Rules and the ICC Rules offer some flexibility allowing parties to apply for an interim relief even before the commencement of the arbitration proceedings. ${ }^{45}$ The party is then required to submit a Request for Arbitration within a certain period of time after the application for relief, otherwise the emergency procedures will be terminated. ${ }^{46}$ The rather short period of time both under the ICC Rules and SCC Rules (10 days) indicates that parties have to have already formulated their Request for Arbitration before they file emergency relief request. Conversely, the AAA/ICDR Rules are silent in this regard.

The final limit for the application is either (i) the date of the transmission of the file to the arbitral tribunal (the ICC Rules and the SCC Rules) or (ii) the date of constitution of the arbitral tribunal (the SIAC Rules, the LCIA Rules and the AAA/ICDR Rules). Even if it may initially seem that there is not much difference between the above two moments, in practice there is. Under the ICC Rules, the Secretariat will only transmit the file to the arbitral tribunal if the advance on costs requested by the Secretariat has been paid, ${ }^{47}$ which means that between tribunal's constitution and the delivery of the file a considerable amount of time may elapse.

The most important question relates to the specific grounds for requiring the appointment of the emergency arbitrator. Shall the standard of "emergency" for invoking the emergency procedure be different of the standard required for application for interim measures in the course of arbitration proceedings?

Under the ICC Rules, the scope of application of the emergency arbitrator proceedings is limited to truly urgent situations "which cannot await the constitution of an arbitral tribunal" and "parties in need of urgency". 48 The urgency is a substantive condition for the issuance of an order and it is upon the emergency arbitrator to determine whether the condition was met. The SIAC Rules refer

43 Schedule 1(1) of the SIAC Rules.

44 Article 9.4 of the LCIA Arbitration Rules.

45 Article 29 ICC Rules, Appendix II, Article 32(4) of the SCC Rules.

46 Under Appendix V, Article 1(6) of the ICC Rules, the time limit is 10 days after the application. SCC Rules are even more generous and according to Appendix II, Article 9(4), the arbitration proceedings must commence within 30 days from the date of the emergency decision.

47 Article 16 of the ICC Rules.

48 Article 29(1) of the ICC Rules. 
to "party that wishes to seek emergency interim relief" 49 and the LCIA Rules to the application of this procedure "in the case of emergency". ${ }^{50}$ Under the Swiss Arbitration Rules the applicant must state in its application "the reason for the purported urgency" and the emergency arbitrator will have to decide whether urgency justifies the requested measures. The SCC Rules do not make an express reference to "urgency" but the measure per se is perceived in the emergency context and based on the available emergency arbitrator decisions the urgency is part of the reasoning.

As follows from the above it can be said that under all the rules the applicant must prove not only the urgency of the application in the sense of conventional interim measures, but also the "emergency" in the sense that the requested measure cannot await the constitution of the tribunal. Save for the "emergency" requirement the arbitration rules do not prescribe any substantive standard for the grant of emergency provisional measures. Looking at the case law available it appears that the emergency arbitrators applied, with different emphasis, the following criteria when examining the applications for emergency relief: (a) whether there is a prima facie jurisdiction over the claim, (b) whether the applicant has a prima facie case on the merits or has a chance of success, (c) whether urgency justifies the requested relief, (d) whether there is a risk of irreparable harm if the request is denied ${ }^{51}$ and (e) proportionality, i.e. whether the harm avoided is greater than the harm that the respondent would potentially suffer as a result of the emergency measure..$^{52}$

The emergency arbitrator's powers are, generally, the same as those of the regular arbitral tribunal deciding on interim measures. All of the analyzed rules adopted a minimalistic approach in regulation and the emergency arbitrator can grant any interim measure that it finds appropriate. The emergency arbitrators,

49 Schedule 1, Article 11 of the SIAC Rules.

50 Article 9.4 of the LCIA Rules.

51 Emergency arbitration awards in Evrobalt and Kompozit (described further in the text) which reached different conclusions on the issue of irreparable harm over the same set of facts demonstrate that the issue whether the possibility of monetary compensation is sufficient to bar an application for interim relief is far from being settled and the case law will further develop.

52 MAGNUSSON, Annette. SCC Emergency Arbitrator Proceedings. [online]. Available at: http://www.sccinstitute.com/media/56037/aprag-2013_scc-practice-2010-2013-emergency-arbitrator-2.pdf Accessed: 1.3.2018, pp. 8-17. SWISS CHAMBERS' ARBITRATION ISTITUTION. Emergency Relief under the Swiss Rules (Art. 43) An overview after 4 years of practice. [online]. Available at: https://www.swissarbitration.org/files/620/untitled\%20 folder/Emergency\%20Proceedings\%20under\%20the\%20Swiss\%20Rules\%20(2017).pdf> Accessed: 1.3.2018, p. 2. See also HAVEDAL, Anja. SCC Practice Note. Emergency Arbitrator Decisions Rendered 2015-2016. [online]. Available at: http://www.sccinstitute.com/ media/194250/ea-practice-note-emergency-arbitrator-decisions-rendered-2015-2016.pdf Accessed: 1.3.2018, pp. 17-18. 
thus, can have more flexibility to order interim measures than an ordinary court usually has.

As regards the conduct of the proceedings, the emergency arbitrator has wide discretion and is not required to hold a hearing and may decide the application for emergency relief on the basis of documents presented. The entire procedure is designed in an expedited fashion, however, due process guarantees of equal treatment and the right to be heard must be observed.

While ex parte proceedings are not allowed under all of the analyzed rules, the emergency proceedings may take place and a decision may be rendered even if the respondent fails to respond or appear at a scheduled hearing. Modern technologies will usually be used to provide an opportunity for parties to participate in a hearing. The Swiss Arbitration Rules make it possible for the emergency arbitrator to issue, in exceptional circumstances, a preliminary order before the request has been communicated to any other party, provided that such communication is made at the latest together with the preliminary order and that the other parties are immediately granted an opportunity to be heard..$^{53}$

The ICC Rules and the SIAC rules do not set a fixed deadline for a respondent's answer. It will be determined in the procedural timetable to be drawn up by the emergency arbitrator depending on circumstances of each case.

Based on the publicly available summaries of the emergency arbitrator decisions, the types of emergency measures sought by the parties have been diverse. Requests were predominantly made for negative injunctions such as injunctions to refrain from disposing of or encumbering shares or other assets, from selling goods, from disclosing information, from collecting amounts under a guarantee, from starting parallel proceedings before ordinary courts or taking an action that would deprive an applicant from a contractual right. ${ }^{54}$ Requests for a specific performance included for example orders to deliver certain products or documentation, to store products, to provide an access to maintenance services, or to move for a stay of the claim before a state court pending the rendering of a final arbitral award. ${ }^{55}$ Like a full arbitral tribunal, the emergency arbitrator is not able to grant interim orders over third parties to the (eventual) arbitration proceedings.

53 Articles 26(3) and 43(1) of the Swiss Arbitration Rules.

54 MAGNUSSON, Annette. SCC Emergency Arbitrator Proceedings. [online]. Available at: http://www.sccinstitute.com/media/56037/aprag-2013_scc-practice-2010-2013-emergency-arbitrator-2.pdf Accessed: 1.3.2018, pp. 8-17. SWISS CHAMBERS' ARBITRATION ISTITUTION. Emergency Relief under the Swiss Rules (Art. 43) An overview after 4 years of practice. [online]. Available at: https://www.swissarbitration.org/files/620/untitled\%20 folder/Emergency\%20Proceedings\%20under\%20the\%20Swiss\%20Rules\%20(2017).pdf> Accessed: 1.3.2018, p. 2.

55 Ibid. 
The deadlines for issuing an emergency decision are extremely short and vary in the rules from 5 to 15 days. Pursuant to the LCIA and SIAC Rules "as soon as possible and by no later than 14 days from appointment", ${ }^{56}$ under the Swiss Arbitration Rules and ICC Rules the emergency arbitrator renders a decision "within 15 days from the date on which the file was transmitted to it", ${ }^{57}$ and the SCC Rules require the emergency arbitrator decision to be made "not later than five days from the date when the application was referred to the emergency arbitrator" 58 The time limits may be extended by the consent of the parties or upon a reasoned request by the emergency arbitrator towards the relevant arbitration institution or its body.

The emergency arbitrators are empowered to require the applicant to provide appropriate security as a pre-condition to granting of relief. ${ }^{59}$ This should secure coverage of potential damage the orders/awards may cause if wrongly granted against innocent parties.

\subsection{Concurrent Jurisdiction of a Competent Court}

As regards the relationship with courts, emergency arbitrator procedures are not envisaged to represent an exclusive remedy and, in general, the submission to those proceedings does not operate as a waiver of a judicial authority over the matter ${ }^{60}$ Any party can address any competent court notwithstanding the existence of the emergency arbitrator procedures. In some instances state courts will remain the only viable option for the applicant, for example in a need for ex parte relief.

In case of the ICC Rules, however, once an application for emergency measure has been filed, parties can only seek urgent interim relief from a court "in appropriate circumstances". ${ }^{61}$ What constitutes "appropriate circumstances" will be determined by the relevant court on a case-by-case basis. The ICC Rules contain one more specificity, i.e. the emergency arbitrator procedures do not apply, if parties have agreed to another pre-arbitral procedure that provides for the granting of interim measures. ${ }^{62}$

56 Article 9.8 of the LCIA Rules and Schedule 1, Article 9 of the Swiss Arbitration Rules.

57 Art. 43(7) of Swiss Arbitration Rules and Appendix V, Article 6.4 of the ICC Rules.

58 Appendix II, Article 8 of the SCC Rules.

59 Appendix V, Article 6(7) of the ICC Rules, Schedule 1, Article 11 of the SIAC Rules.

60 Article 29(7) of the ICC Rules, Article 26(5) of the Swiss Arbitration Rules.

61 Article 29(7) of the ICC Rules.

62 Article 29(6)(c) was included upon the request of FIDIC contract users that wanted to ensure the applicability of specific interim relief provisions regulated in the FIDIC contracts. The provision was, however, criticized as it will be difficult for the President of the Court to examine in each contract whether parties agreed on pre-arbitral procedures meeting the criteria of Article 29(6)(c), i.e. that the agreed procedure provides for the granting of the "conservatory, interim or similar measures ". See VOSER, Nathalie. Overview of the Most Important Changes in the Revised ICC Arbitration Rules. ASA Bulletin, 2011, no. 4, pp. 814-815. 
It has to be noted that the provision of mandatory local law may curtail recourse to the courts where parties have an option to seek relief from another source, including the emergency arbitration. ${ }^{63}$

\subsection{Enforcement of Emergency Arbitrator's Decisions}

The form of the relief granted by the emergency arbitrator varies in the analyzed rules. The SCC Rules, the AAA/ICDR Rules and the SIAC Rules permit interim "awards", 64 the ICC Rules impose "orders" 65 (which will not be subject to the ICC Court's scrutiny). Under the Swiss Arbitration Rules the decision may take the form of an award or may initially be granted by way of a preliminary order. $^{66}$

Orders or awards of the emergency arbitrator are binding on the parties when rendered. They do not bind the subsequently constituted arbitral tribunal. The full tribunal is empowered to reconsider, modify, terminate or annul the order or award. ${ }^{67}$ In general, the decisions also lapse upon the following events: (a) the emergency arbitrator decides otherwise, (b) a Request for Arbitration is not filed within relevant deadline (where filing application for the emergency measures is possible even before commencing the arbitration proceedings) or (c) when a final award is made.

The designation of the emergency arbitrator's decision as an award or an order does not have any impact on whether orders issued by emergency arbitrators can be recognized and enforced in any jurisdiction. Just like interim reliefs granted after the appointment of the regular tribunals, the question of recognition and enforcement of emergency measures will depend on relevant national arbitration laws and international conventions. The answer will mostly be negative and such awards are, according to prevailing opinions, neither enforceable under the New York Convention on the Recognition and Enforcement of Foreign Arbitral Awards. ${ }^{68}$ Nonetheless, jurisdictions which have adopted or will adopt

63 For example, English courts will grant orders in support of arbitration if and to the extent the arbitral tribunal or person vested by the parties with power in that regard, has no power or is unable for the time being act effectively. See Article 44(5) of the English Arbitration Act 1996.

64 Schedule 1(6) of the SIAC Rules, Article 32(3) of the SCC Rules.

65 Article 29(6) of the ICC Rules.

66 Articles $43(8)$ and $26(2,3)$ the Swiss Arbitration Rules.

67 Article 29(3) of the ICC Rules, Schedule 1(7) of the SIAC Rules. Article 43.8 of the Swiss Arbitration Rules, Article 9.11 of the LCIA Rules.

68 Contrary, e.g. Decision of the Specialized Higher Court of Ukraine no. 6-30579ck15 dated 24 February 2016 in case JKX Oil \& Gas plc, Poltava Gas B.V. and Poltava Petroleum Company JV v Ukraine (SCC, EA/2015/002), in which the court, without detailed reasoning, concluded that the enforcement of an emergency arbitrator decision is governed by the New York Convention. 
the revised UNCITRAL Model Law 2006, including Articles $17 \mathrm{H}^{69}$ and $17 \mathrm{I}^{70}$, are likely to recognize and enforce orders issued by the emergency arbitrators.

The question basically revolves around two arguments, one is addressing whether the emergency arbitrator equates with an "arbitral tribunal" defined in the UNCITRAL Model Law and the other underlines the temporary nature of the emergency arbitrator's decision. As stated above, the proper arbitral tribunal may revoke or modify the measures granted by the emergency arbitrator at any time. It runs against the natural instinct that a decision susceptible for enforcement shall be final and binding. This, however, similarly applies to any decisions on interim measures. It has to be noted that parties very often comply with interim measures voluntarily and the issue of enforceability then does not arise. ${ }^{71}$

Separately, all the compared arbitration rules require the parties to comply with the order of the emergency arbitrator. Any non-compliance will, thus, represent a breach of contract and arbitral tribunals are empowered to reflect it in the final award on damages (e.g. Article 29(4) of the ICC Rules).

\section{Legal basis of emergency arbitrator's power}

In general, the national arbitration laws do not expressly provide legislative support for pre-arbitral proceedings and measures. The question becomes whether the pre-arbitral proceedings are based on party autonomy only. The answer is delicate in particular when considering pre-arbitral relief that precedes the commencement of arbitral proceeding and when considering the legal effects of decisions made by the emergency arbitrators.

Even if the relevant national laws specifically provide that arbitral tribunals may order interim relief (which is the case relating to the rules compared in this paper) the question arises as to whether the decision of the emergency arbitrator falls within such statutory provision and emergency arbitrators classify as proper "arbitrators". If not, then emergency arbitrator's decisions are based solely on the parties' agreement to apply the relevant arbitration rules and the nature of the emergency arbitrator's decision in the form of an enforceable award can be questioned.

69 Article $17 \mathrm{H} \mathrm{(1)}$ of the Model Law 2006 stipulates as follows: "An interim measure issued by an arbitral tribunal shall be recognized as binding and, unless otherwise provided by the arbitral tribunal, enforced upon application to the competent court, irrespective of the country in which it was issued, subject to the provisions of article 17 I."

70 Article $17 \mathrm{H}$ (1) of the Model Law 2006 stipulates grounds for refusing recognition or enforcement. Further, it is explicitly stated that the court where recognition or enforcement is sought shall not review the substance of the interim measure.

71 See e.g. HAVEDAL, Anja. SCC Practice Note. Emergency Arbitrator Decisions Rendered 2015-2016. [online]. Available at: http://www.sccinstitute.com/media/194250/ea-practice-note-emergency-arbitrator-decisions-rendered-2015-2016.pdf Accessed: 1.3.2018, p. 18. 
There has been no final answer yet as to whether the emergency arbitrator procedure lacks a statutory base, whether a statutory base is actually required and what the consequences might be. Commentators in Sweden state that "the power of an arbitral tribunal to issue partial or interim awards, including on provisional measures, may derive from the arbitration agreement or the applicable law".72 Taking the same logic, if parties are able to empower arbitrators to make decisions on interim measures, what principle would be served by limiting the parties' ability to empower emergency arbitrators (not the administrative bodies of the relevant arbitration institutions) to issue an urgent interim relief? The assessment of these questions will ultimately depend on the national legislation and the attitude of the courts of the seat of arbitration and at the place where enforcement of an emergency arbitrator decision will be sought (including relevant international treaties and conventions).

Under all the compared rules, the relevant bodies appointing the emergency arbitrator can decide on the seat of the emergency proceedings if the arbitration agreement does not provide for the seat of arbitration. In determining the seat it will be important to ensure that the law of the seat or relevant doctrine allows for such emergency proceedings. Only the SIAC Rules envisage a default seat of the proceedings to be Singapore. It appears that the parties are free to establish a different seat for the emergency proceedings and the subsequent arbitration proceedings.

\section{Emergency measures in investment arbitration}

In a number of circumstances the practice has shown that investment arbitration gives rise to issues that are not normally present in international commercial arbitration, even where a State participates in the commercial arbitration proceedings. With respect to the emergency arbitrator mechanism in the investment arbitration context questions may arise when it comes to the requirement of the cooling off period or the content of the host State's consent to the arbitration procedure. Further, the fact itself that various arbitration institutions adopted diverging attitudes towards the application of the emergency arbitrator procedure provokes queries as to whether this new mechanism is suitable for investment treaty disputes.

The most commonly used legal instruments in investment treaties such as the Convention on the Settlement of Investment Disputes between States and Nationals of other States (the "ICSID Convention"), including the ICSID Arbitration Rules, and the UNCITRAL Arbitration Rules ${ }^{73}$ do not contain emergency

72 SHAUGHNESSY, Patricia. Pre-Arbitral Urgent Relief: The New SCC Emergency Arbitrator Rules. Journal of International Arbitration, 2010, vol. 27, no. 4, p. 357.

73 Arbitration Rules of the United Nations Commission on International Trade Law in all three available versions, i.e. the 1976 version, the revised 2010 version, and the 2013 version which incorporates the UNCITRAL Rules on Transparency for Treaty-based Inves- 
arbitrator provisions. It is apparent that at present there is no activity for incorporating emergency arbitrator provisions into those rules. The current amendment process launched by ICSID in October 2016 does not list emergency measures among the topics identified for potential rule amendment. ${ }^{74}$

The ICC Rules stipulating emergency arbitrator provisions also indirectly exclude their application to investment treaty disputes given the specific mechanism of formation of consent in investment cases under which the investor and the host State cannot be considered "signatories of the arbitration agreement" as required by the ICC Arbitration Rules. ${ }^{75}$ Some commentators indicate that the exclusion of investment cases is rather a policy decision of the ICC than rigorous interpretation of Article 29(5) of the ICC Rules and the consent of the host State to arbitration. ${ }^{76}$ The reasons behind this policy are not publicly known.

Contrary, the SCC Rules do not differentiate between commercial and investment arbitration and their emergency arbitrator provisions have been already used in the first investment cases. ${ }^{77}$ The SCC Rules are contemplated in a number of bilateral investment treaties ("BITs") and primarily in the Energy Charter Treaty, which is a frequently invoked legal basis for energy investment disputes and the use of emergency provisions in the SCC Rules, thus, shall not be expected to be modest.

The cases arbitrated pursuant to the emergency arbitrator provisions of the SCC Rules and which were made public reveal that the tool has been effectively applied without any major obstacles, which would be given due to the participation of the State in the proceedings or to specificities of the investment treaty arbitration. At the same time it has to be, however, noted that none of the issues outlined below was discussed in the emergency arbitrator decisions at length.

From a practical perspective, it is indisputable that for a State apparatus it can be challenging to meet one-day deadlines and to properly defend its rights. Special expertise is needed for this type of disputes and States often hire external

tor-State Arbitration.

74 ICSID SECRETARIAT. The ICSID Rules Amendment Process. [online]. Available at: https://icsid.worldbank.org/en/Documents/about/ICSID\%20Rules\%20Amendment\%20 Process-ENG.pdf. Accessed: 1.3.2018, pp 2-3.

75 See Article 29(5) of the ICC Rules.

76 See e.g. PINSOLLE, Philippe. A Call to Open the ICC Emergency Arbitrator Procedure to Investment Treaty Cases. In CARLEVARIS, Andrea, LÉVY, Laurent, MOURRE, Alexis, SCHWARTZ, Eric (eds.) International Arbitration under Review. Essays in Honor of John Beechey. International Chamber of Commerce, 2015, p. 308.

77 As noted in supra 2, only in 2016 thirteen emergency arbitrator proceedings were commenced at the SCC. The first decided cases since 2014 included TSIKInvest v Republic of Moldova; JKX Oil \& Gas plc, Poltava Gas B.V. and Poltava Petroleum Company JV v Ukraine; Evrobalt LLC v Republic of Moldova; Kompozit LLC v Republic of Moldova. Emergency arbitrator decisions which are publicly available can be accessed at https:// www.italaw.com/search/site/Emergency. 
counsels. The reality of public tender procedures, which is not present in respect of commercial actors, cannot be omitted lightly. This circumstance might call into question the general basis of procedural fairness. Interestingly, the Supreme Court of Ukraine when reviewing the enforceability of emergency decision in case JKX Oil \& Gas expressly stated that the time limits for the State were sufficient. ${ }^{78}$ In addition, under the SCC Rules the applicant can ask for the appointment of the emergency arbitrator before the Request for Arbitration is filed, so the emergency arbitrator application will be a surprise and issues of due process and lack of procedural fairness can be at issue.

The interim protection of rights is a core principle in many legal systems and the presence of emergency arbitrators in investment treaty disputes will likely be seen more in the future. The practice will show where the trend of other institutions will go. The SCC emergency arbitration awards so far show that the prospects of obtaining emergency interim relief against a sovereign State are not straightforward. In particular the awards in Evrobalt and Kompozit in which each emergency arbitrator reached a different conclusion based on similar factual and legal circumstances ${ }^{79}$ demonstrates that the criteria for granting emergency interim measures will be further refined.

\subsection{Consent of the State}

Save for few treaties negotiated or re-negotiated in the last seven years, investment treaties in which the State consented to arbitration originate from the time when emergency arbitration did not exist and predate the 2010 version of the SCC Rules. The principal question then becomes of whether the State is to be deemed to have consented to emergency arbitration procedure. The wording used in the treaties usually does not refer to a certain edition of the arbitration rules to be used. In such cases it is generally accepted that the version of the arbitration rules valid at the time of the Request for Arbitration applies.

As already mentioned the emergency provisions of the SCC Rules apply to all arbitrations commenced after 1 January 2010 irrespective of the date of the arbitration agreement (unlike for the ICC Rules in the commercial arbitration context). The considerations of the opt-in and opt-out approach described above are fully relevant here. Unlike the SCC Rules, the new ICC Rules apply to arbitration agreements concluded after the entry into force of the ICC Rules emphasizing the predictability for the parties. Moreover, the ICC Rules limit the application of the emergency provisions to contractual cases.

78 Decision of the Specialized Higher Court of Ukraine no. 6-30579ck15 dated 24 February 2016 in case JKX Oil \& Gas plc, Poltava Gas B.V. and Poltava Petroleum Company JV v Ukraine (SCC, EA/2015/002).

79 Claimants in both proceedings, Evrobalt LLC and Kompozit LLC, were companies incorporated in Russia and shareholders of Moldova Agroindbank facing the same suspension and disinvestment measure of the state National Bank. 
Similar arguments about predictability were put forward when adopting the 2010 version of the UNCITRAL Rules and considering their temporal application. The presumption of application of the new version of the rules does not apply where the arbitration agreement has been concluded by accepting after 15 August 2010 an offer made before that date. This means that where the relevant bilateral or multilateral investment treaty predates 2010 and the Request for Arbitration is made after 2010, the 1976 UNCITRAL Arbitration Rules will apply. ${ }^{80}$

The "retroactive" applicability of the emergency provisions contained in 2010 SCC Arbitration Rules with respect to disputes arising out of bilateral investment treaties concluded before 2010 have been tested in two emergency arbitrator cases, Evrobalt ${ }^{81}$ and Kompozit. ${ }^{82}$ In both the cases, the Republic of Moldova as the respondent contested jurisdiction of the emergency arbitrator objecting that at the time of signing of the relevant BIT in 1998 Moldova envisaged a previous version of the SCC Rules, not containing any emergency arbitrator procedure. Moldova, thus, has not given consent to submit to the emergency procedure which Moldova claimed to represent an extraordinary qualitative change of the arbitration rules by giving adjudicative functions to a body different from the arbitral tribunal. ${ }^{83}$

The emergency arbitrators emphasized that no agreement or no specific mention was made in the BIT regarding the version of the SCC Arbitration Rules that should apply to the disputes covered by the BIT. Moreover, at the time of the signature of the BIT, the 1988 version of the Arbitration Rules was applicable. When the BIT was ratified by the Russian Federation in 2001, new version of the SCC Arbitration Rules of 1999 came into effect. ${ }^{84}$ Under the Preamble to the 2010 version of the SCC Arbitration Rules, any reference to the SCC arbitration in the arbitration agreement shall mean the rules in force on the date of the filing of an application for emergency arbitration, unless otherwise agreed between the parties. The emergency arbitrators concluded that had the contracting parties wished to freeze any applicable version of the SCC Arbitration Rules, they would have provided for it in the BIT. In the absence of such specific mention, the application of the 2010 SCC Arbitration Rules, including provisions on emergency arbitrator procedure, were within the reasonable contemplation of the parties to the BIT. ${ }^{85}$

80 See Article 1 (2) of the UNCITRAL Arbitration Rules (2010 version).

81 Evrobalt LLC v Republic of Moldova; SCC Arbitration EA (2016/082). Available at: https:// www.italaw.com/sites/default/files/case-documents/italaw7410.pdf

82 Kompozit LLC v Republic of Moldova. SCC Arbitration EA (2016/095). Available at: https://www.italaw.com/sites/default/files/case-documents/italaw7421.pdf

83 Decision of the Emergency Arbitrator dated 14 June 2016 (in case Kompozit LLC v Republic of Moldova. SCC Arbitration EA (2016/095), para 42.

84 Ibid., para 38.

85 Ibid., para 44. Decision of the Emergency Arbitrator dated 30 May 2016 (in case Evrobalt 


\subsection{Cooling off periods}

In none of the decided cases a pending cooling off period prevented the emergency arbitrators in rendering their decisions. The cooling off period is envisaged in a number of investment treaties. It may range between 3 and 18 months within which the parties to the dispute shall try to resolve the dispute amicably. Only after the elapse of such period an investor can start the arbitration proceedings.

In Evrobalt and Kompozit cases the 6-month period between the Notice of Claim and the Request for Arbitration ${ }^{86}$ did not expire at the moment of filing the application for emergency measure. The claimant stated that if the cooling off period applied to the appointment of the emergency arbitrator, then the emergency arbitrator procedure would be deprived of its purpose. ${ }^{87}$

Both emergency arbitrators concluded that the pending cooling off period does not constitute a bar to the emergency arbitrator's jurisdiction. According to the emergency arbitrators, this is irrespective of phrasing the cooling off period as a procedural issue pointing to jurisdiction or as an issue of admissibility of the claim. ${ }^{88}$ Even though the views on the characterization of the cooling off period are still divergent, both emergency arbitrators inclined to consider it of procedural nature rather than jurisdictional and mandatory, without detailed reasoning. Moldova's refusal to engage in amicable settlement with the claimant or to suspend the regulatory measure made it, according to the opinion of the emergency arbitrators, futile to insist on the exhaustion of the cooling off period. ${ }^{89}$ The emergency arbitrator in the Kompozit case further stressed out the language used in Article 10 of the BIT, i.e. to settle the dispute amicably "as far as possible". The langue suggests that after failing the attempt at amicable settlement the parties can proceed with the arbitration proceedings. ${ }^{90}$ It is obvious that compliance or non-compliance with the cooling off period may have a significant impact on the validity of the emergency decision and its potential enforcement, if available.

LLC v Republic of Moldova; SCC Arbitration EA (2016/082), paras 39-30.

86 Article 10(1) and (2) of the BIT states: "the Parties in dispute will try, as far as possible, to resolve such dispute amicably....if the dispute is not resolved in such a way within six months from the date of written notification... it shall be submitted for consideration to: . . . (b) the Arbitration Institute of the [SCC]." See also Decision of the Emergency Arbitrator dated 14 June 2016 (in case Kompozit LLC v Republic of Moldova. SCC Arbitration EA (2016/095), para 20.

87 Decision of the Emergency Arbitrator dated 14 June 2016 (in case Kompozit LLC v Republic of Moldova. SCC Arbitration EA (2016/095), para 54 (a). Available at: https://www. italaw.com/sites/default/files/case-documents/italaw7391.pdf. Accessed: 1.3.2018.

88 Decision of the Emergency Arbitrator dated 30 May 2016 (in case Evrobalt LLC v Republic of Moldova; SCC Arbitration EA (2016/082), paras 22.

89 Ibid., para 56.

90 Ibid., para 55. 
A related question with might arise in the investment arbitration context is the use of most favored nation clauses ("MFN") and their ability to import procedural provisions from other treaties or to skip the above cooling off periods. There has been a historic academic debate and disagreement about the reach of MFN clauses as regards the possibility of the MFN clause to entirely replace the dispute resolution provisions in one treaty with provision of another treaty or its limitation to procedural issues or admissibility requirements. ${ }^{91}$

From a claimant's perspective a dispute resolution clause with the possibility of seeking redress from an emergency arbitrator can be objectively considered more favorable than arbitration without such a possibility. Reference to another treaty via the MFN clause can be considered in two main circumstances. One of them might be the need to overcome the cooling off period contained in the basic treaty which is missing in the reference treaty. Another situation can be an attempt to import access to emergency arbitrator procedure where the relevant rules do not provide such a feature (e.g. ICSID Arbitration Rules or the UNCITRAL Arbitration Rules). This will bring another complexity to the decision making of the emergency arbitrator which must be per se very quick and the emergency arbitrator will not have time to elaborate at length on some of the issues over which there is no universal agreement yet.

\section{Conclusion}

Generally, the users' response to the emergency arbitrator procedure has been so far positive. The growing body of case law also shows that a decision can be obtained within the short time limits stipulated in the rules. The increasing use is encouraged by the automatic inclusion of the emergency provisions in the arbitration rules through the opt-out approach.

Although there may be certain practical limitation on the enforcement of the emergency arbitrator provisions, the ultimate objective is to increase party autonomy and reduce the role of the courts in arbitral proceedings. As some authors stress, the emergency arbitrator rules allow parties to seek urgent interim relief "without scarifying their bargained-for expectation of resolving their dispute in a private forum with the flexible procedures and options offered by arbitration". 92

91 See e.g. DOUGLAS, Zachary. The MFN Clause in Investment Arbitration: Treaty Interpretation Off the Rails. Journal of International Dispute Settlement. 2011, vol. 2. Issue 1, pp. 97-114 (claiming that extension of the MFN clause to dispute settlement provisions will "undermine the possibility of a valid and binding arbitration agreement"), and a reply of Schill in SCHILL, Stephan. Allocating Adjudicatory Authority: Most-Favoured-Nation Clauses as a Basis of Jurisdiction-A Reply to Zachary Douglas. Journal of International Dispute Settlement. 2011, Vol. 2, Issue 2, pp. 353-371 (arguing that MFN clauses can serve as a jurisdictional basis in investment treaty arbitration).

92 SHAUGHNESSY, Patricia. Pre-Arbitral Urgent Relief: The New SCC Emergency Arbitrator Rules. Journal of International Arbitration, 2010, vol. 27, no. 4, p. 338. 
For respondents it might be difficult to immediately allocate time and resources necessary for responding to the application for emergency measures. A potential future respondent in urgent interim relief proceedings (such as a licensee), thus might consider opting out the possibility of the application of the emergency arbitrator provisions when negotiating arbitration clauses. It is advisable that a potential respondent adopts a defense policy in advance, such as determining who in the organization will make a decision and who will supply information. If an emergency arbitrator's application arrives, the organization will be ready to respond to the application in a timeframe set out by the emergency arbitrator.

If wisely used, the emergency arbitrator procedure has added a new practical dimension to the settlement of disputes through arbitration and to the protection of parties' rights. In particular, interim measures ordering the suspension of parallel proceedings or otherwise affecting such proceedings seem to be growing in numbers. Requests for interim measures in investor-state arbitrations have met with mixed success.

\section{References}

BLACKABY, Nigel, PARTASIDES, Constantine, et al. Redfern and Hunter on International Arbitration. Oxford University Press, 2009.

BOOG, Christopher. Swiss Rules of International Arbitration - Time to Introduce an Emergency Arbitrator Procedure? ASA Bulletin, 2010, 3, pp. 463-465.

BÜHLER, Michael. ICC Pre-Arbitral Referee and Emergency Arbitrator Proceedings Compared. ICC International Arbitration Bulletin., 2011, vol. 22, Special Supplement, pp. 93-98.

DOUGLAS, Zachary. The MFN Clause in Investment Arbitration: Treaty Interpretation Off the Rails. Journal of International Dispute Settlement. 2011, vol. 2. Issue 1, pp. 97-114.

HAVEDAL, Anja. SCC Practice Note. Emergency Arbitrator Decisions Rendered 20152016. [online]. Available at: http://www.sccinstitute.com/media/194250/ea-practicenote-emergency-arbitrator-decisions-rendered-2015-2016.pdf

MAGNUSSON, Annette. SCC Emergency Arbitrator Proceedings. [online]. Available at: http://www.sccinstitute.com/media/56037/aprag-2013_scc-practice2010-2013-emergency-arbitrator-2.pdf

PINSOLLE, Philippe. A Call to Open the ICC Emergency Arbitrator Procedure to Investment Treaty Cases. In CARLEVARIS, Andrea, LÉVY, Laurent, MOURRE, Alexis, SCHWARTZ, Eric (eds.) International Arbitration under Review. Essays in Honor of John Beechey. International Chamber of Commerce, 2015.

SCHILL, Stephan. Allocating Adjudicatory Authority: Most-Favoured-Nation Clauses as a Basis of Jurisdiction-A Reply to Zachary Douglas. Journal of International Dispute Settlement. 2011, Vol. 2, Issue 2, pp. 353-371

SHAUGHNESSY, Patricia. Pre-Arbitral Urgent Relief: The New SCC Emergency Arbitrator Rules. Journal of International Arbitration, 2010, vol. 27, no. 4, pp. 337-360.

VOSER, Nathalie. Overview of the Most Important Changes in the Revised ICC Arbitration Rules. ASA Bulletin, 2011, no. 4, pp. 814-815. 